\title{
Adrenocortical corticotropic insufficiency secondary to the use of cosmetic dermocorticoids
}

\author{
Annelie Kérékou Hodé*, Hubert Dédjan \\ Department of Endocrinology, Metabolism and Nutrition, CNHU-HKM Cotonou, Bénin
}

\begin{abstract}
Voluntary depigmentation or artificial depigmentation for cosmetic purposes is a very widespread phenomenon in Africa. The prevalence reported by several authors varies from 26 to $67 \%$. The complications linked to their use are numerous and less known by the population. We report two cases of acute adrenocortical insufficiency secondary to the use of cosmetic dermocorticoids in diabetic patients aged 40 and 53 years respectively. They were admitted with signs of ketoacidosis decompensation which were similar to signs of acute adrenal insufficiency. The cases' history revealed that they were using dermocorticoids. The clinical examination identified in both patients a systemic inflammatory response syndrome and general depigmentation. The 40-year-old patient had erysipelas of the left leg and the 53-year-old patient had a diabetic foot with a neuropathic and infectious mechanism. Laboratory tests revealed hyperglycemia, massive acetonuria and a low 8-hour cortisol. The clinical outcome was favorable after hydro-electrolytic rehydration, hourly intravenous insulin therapy, hydrocortisone and antibiotic therapy. Corticotropic insufficiency secondary to voluntary depigmentation by dermocorticoids is a complication that should be systematically sought in any subject using dermocorticoids. Hydrocortisone substitution should be done without delay in the event of confirmed corticotropic insufficiency.
\end{abstract}

Keywords: corticotropic adrenal insufficiency; dermocorticoids; voluntary depigmentation; diabetes; hydrocortisone

\section{Introduction}

Voluntary depigmentation or artificial depigmentation for cosmetic purposes is a very widespread phenomenon in Africa. The prevalence found by several authors varies from 26 to $67 \%$ [1-6]. The main products used are hydroquinone (24-89\%), dermocorticoids (18.5-70\%), and mercury products (10-31\%) [7]. The complications linked to this practice are numerous and less known to the population.

Received: November 2019; Accepted after review: December 2019; Published: December 2019.

${ }^{*}$ Corresponding author: Annelie Kérékou Hodé, Department of Endocrinology, Metabolism and Nutrition, CNHU-HKM 01 BP386, Cotonou, Bénin.

Tel: 0022921300155

Email: anneliekerekou@yahoo.fr
These are mainly dermatoses such as diffuse dermatophytosis, cortisonic acne, stretch marks, dyschromia, exogenous ochronosis, skin atrophy, irritant dermatitis, eczematiform dermatitis, systemic complications such as diabetes, arterial hypertension and corticotropic insufficiency [7].

We report two cases of acute adrenocortical insufficiency secondary to the use of cosmetic dermocorticoids.

\section{Cases presentation}

Case 1

We report the case of a 40-year-old female patient, suffering from diabetes for one year, poorly followed, admitted with signs of worsening polyuropolydipsic syndrome, 
asthenia, weight loss, abdominal pain and vomiting. The case history revealed that she had been using lightening body milk for ten years, which she had stopped using for a month because of current illness. The composition of body milk was made of betamethasone diproprionate $0.05 \%$.

The clinical examination noted a dehydrated patient in poor general condition, feverish at $38.5^{\circ} \mathrm{C}$, a tachycardia at 120 beats/min, hypotension at $80 / 50 \mathrm{mmHg}$, polypnea at $28 \mathrm{cycles} / \mathrm{min}$, a body mass index at $20.5 \mathrm{~kg} / \mathrm{m}^{2}$, a warm and inflammatory cupboard of the entire anterior surface of the left leg, depigmentation of the whole body with thin skin, periorbital hyperpigmentation, hyperpigmentation of the extension surface of the finger and toe joints and large abdominal and stretch marks at the roots of the limbs. Laboratory results revealed a blood sugar at $4.7 \mathrm{~g} / \mathrm{L}$, glucosuria, acetonuria, hyponatremia at $128 \mathrm{mEq} / \mathrm{L}(135-145 \mathrm{mEq} / \mathrm{L})$, kalemia at 4.2 $\mathrm{mEq} / \mathrm{L}$ (3.5-5.4 $\mathrm{mEq} / \mathrm{L})$, low level of 8-hour cortisol at $28 \mathrm{nmol} / \mathrm{L}(55.9-287 \mathrm{nmol} / \mathrm{L})$. The investigation of hormone adrenocorticotropic (ACTH) was not available. The diagnoses of diabetic ketoacidosis and acute decompensation of adrenocorticotropic insufficiency were retained. In this context we considered that the decompensation factor was erysipelas of the left leg. The treatment consisted of hydro-electrolytic rehydration, hourly intravenous insulin therapy, and injectable solumedrol in the absence of injectable hydrocortisone and antibiotic therapy based on Augmentin $1 \mathrm{~g}, 3$ times a day. The clinical outcome was favorable and patient was released on metformin $1 \mathrm{~g}$, three times a day and on hydrocortisone $15 \mathrm{mg}$ in the morning and $5 \mathrm{mg}$ at $1 \mathrm{pm}$. Thus, the patient benefited of an Addisonian card and she was educated to double the doses of hydrocortisone in case of fever, infection and trauma.

Case 2

A 53-year-old female patient known with diabetes for 5 years was admitted to our clinic due to worsening polyuropolydipsic syndrome, asthenia, nausea, and lesions that appeared in the right foot 3 weeks ago. The medical history revealed the use of lightening body milk for twenty years that she had stopped using for 3 weeks because of current illness. The composition of the body milk was made of clobetasol propionate $0.05 \%$.

The clinical examination revealed a poor general condition, feverish at $38.3^{\circ} \mathrm{C}$, a tachycardia at 104 beats/min, a blood pressure at $100 / 60 \mathrm{mmHg}$, a polypnea at 22 cycles $/ \mathrm{min}$, a body mass index at $31.6 \mathrm{~kg} / \mathrm{m}^{2}$, ulceration of the back of the $1^{\text {st }}, 2^{\text {nd }}$ and $3^{\text {rd }}$ right toes exposing the bones, an erythematous face, thin and atrophied skin, hyperpigmentation of the extension face of the finger and toe joints and large horizontal stretch marks on the abdomen and hips. Laboratory results revealed hyperglycemia at $3.5 \mathrm{~g} / \mathrm{L}$, glucosuria, acetonuria, hyponatremia at $132 \mathrm{mEq} / \mathrm{L}(135-145 \mathrm{mEq} / \mathrm{L})$, serum potassium at $4.9 \mathrm{mEq} / \mathrm{L}(3.5-5.4 \mathrm{mEq} / \mathrm{L})$, glycated hemoglobin at $13.6 \% \quad(<7 \%)$ creatinine at $13 \mathrm{mg} / \mathrm{L}(6-14 \mathrm{mg} / \mathrm{L})$ low level of 8-hour cortisol at $18 \mathrm{nmol} / \mathrm{L}$ (55.9-287 nmol/L). ACTH assay was not available. The bacteriological result of pus from foot lesions had identified an Enterobacter cloacae and a multisensitive Klebsiella pneumoniae. We performed radiography of the right foot that highlighted osteitis of the distal phalanges of the $1^{\text {st }}$ and $2^{\text {nd }}$ right toes. The diagnoses of diabetic ketoacidosis and acute decompensation of adrenocorticotropic insufficiency were retained. The decompensation factor was a diabetic foot with a neuropathic and infectious mechanism. The treatment included hydro-electrolytic rehydration, hourly intravenous insulin therapy, injectable solumedrol in the absence of injectable hydrocortisone, antibiotic therapy based on Augmentin $1 \mathrm{~g}, 3$ times a day, ofloxacin $200 \mathrm{mg}$, twice a day, local care and a discharge from the right foot. The clinical outcome was favorable and the patient was released on a twice daily insulin regimen, hydrocortisone $15 \mathrm{mg}$ in the morning and $5 \mathrm{mg}$ at $1 \mathrm{pm}$ and antibiotic therapy (Augmentin in association with Ofloxacin). Moreover, the patient received an Addisonian card and she was educated to double the doses of hydrocortisone in case of fever, infection and trauma. 


\section{Discussion}

The ages of our patients were 40 and 53 years old and fall within the 24-64 age group reported by Kouotou et al. [8]. Voluntary depigmentation is therefore observed to be used by women of different generations. This practice has also been described in men [7]. The quest for beauty is the main motive that determines this practice.

Dermocorticoids are in second line after hydroquinone in the practice of voluntary depigmentation. They are subdivided into 7 classes going from class I (very strong activity) to class VII (less strong activity) [9]. Dermocorticoids whiten the skin by inhibiting pro-opiomelanocortin which is the precursor of the a-melanocyte-stimulating hormone [10].

Our two patients used dermocorticoids of classes I and II which exposed them more to the deleterious effects. The sudden discontinuation of dermocorticoids and the infectious syndrome are responsible for the acute decompensation in our patients.

The interval of using therapeutic dermocorticoids for the suppression of the corticotropic axis varies from five days to eighteen months according to several authors [11]. Compared to the cosmetic use of dermocorticoids in the long term, involving more than $50 \%$ of the body surface [7], the side effects would be amplified.

Complications linked to voluntary depigmentation are numerous, having a very high prevalence. Thus, in several studies carried out in sub-Saharan Africa, the prevalence of complications varies from 50 to $85.4 \%[1,3-5,12]$.

\section{References}

1. Dadzie OE, Petit A. Skin bleaching: highlighting the misuse of cutaneous depigmenting agents. JEADV 2009; 23(7):741-750.

2. Faye $\mathrm{O}$, Keita $\mathrm{S}$, Diakité $\mathrm{FS}$, Konaré $\mathrm{HD}$, Ndiaye HT. Side effects of de-pigmenting products in Bamako, Mali. Int J Dermatol 2005; 44(Suppl. 1):35-36.

3. Ajose FOA. Consequences of skin bleaching in Nigerian men and women. Int $J$ Dermatol 2005; 44(Suppl. 1):41-43.

4. Traoré A, Kadéba JC, Niamba P, Barro F, Ouedraogo L.. Use of cutaneous depigmenting
Perret et al. reported in their cohort, despite the fact that the cohort was limited, 9 out of 12 women who depigmented themselves with dermocorticoids had a low 8hour cortisol level indicating corticotropic insufficiency [13]. Sobngwi et al. also reported a case of corticotropic adrenal insufficiency associated with diabetes mellitus in a patient using dermocorticoids [14]. Our two patients also had diabetes mellitus, the cortico-induced origin of which cannot be ruled out. The use of cosmetic dermocorticoids is responsible for a high frequency of diabetes and high blood pressure, according to several authors $[7,15]$.

\section{Conclusion}

Public awareness of the complications associated with dermocorticoids represents an essential measure. In addition, corticotropic insufficiency secondary to voluntary depigmentation from the use of dermocorticoids is a complication that should be systematically investigated in any patient using dermocorticoids. The 8-hour cortisol level should be measured in this regard. The hydrocortisone substitution should be carried out without delay upon confirmation of corticotropic insufficiency.

\section{Consent}

Written informed consent was obtained from the patient for publication of this case report.

\section{Competing interests}

The authors declare that they have no competing interests. products by women in two towns in Burkina Faso: epidemiologic data, motivations, products and sides effects. Int $J$ Dermatol 2005; 44(Suppl. 1):30-32.

5. Adebajo SB. An epidemiological survey of the use of cosmetic skin lightening cosmetics among traders in Lagos, Nigeria. West Afr $J$ Med 2002; 21(1):51-55.

6. Pitché $P$, Kombaté $K$, Tchangai-Walla $K$. Cosmetic use of skin-bleaching products and associated complications. Int J Dermatol 2005; 44(Suppl. 1):39-40. 
7. Sène $D$, Huong-Boutin DLT, Thiollet M, Barete $S$, Cacoub P, Piette JC. Insuffisance surrénalienne haute symptomatique compliquant l'usage de dermocorticoïdes pour dépigmentation volontaire. Rev Méd Interne 2008; 29(12):1030-1033.

8. Kouotou EA, Bissek AZ, Nouind CC, Defo D, Sieleunou I, Ndam EC. Dépigmentation volontaire: pratiques et dermatoses associées chez les commerçantes de Yaoundé (Cameroun). Ann Dermatol Venerol 2015; 142(6-7):443-445.

9. Lewin C, Malbach HI. Topical corticosteroidinduced adrenocortical insufficiency: clinical implications. Am J Clin Dermatol 2002; 3(3):141-147.

10. Ladizinski B, Mistry N, Kundu RV. Widespread use of toxic skin lightening compounds: Medical and psychosocial aspects. Dermatol Clin 2011; 29(1):111-123.

11. Boëkle B, Jara $D$, Nindi W, Aberer W, Sepp NT. Adrenal insufficiency as a result of long- term misuse of topical corticosteroids. Dermatology 2014; 228(4):289-293.

12. Boyle J, Kennedy CT. Hydroquinone concentrations in skin lightening creams. $\mathrm{Br} J$ Dermatol 1986; 114(4):501-504.

13. Perret JL, Sane M, Gning S, Ba K, Rohou G. Hypothalamo-hypophyseal-adrenal hypofunction caused by the use of bleaching cosmetics in Senegal. Bull Soc Pathol Exot 2001; 94:249-252.

14. Sobngwi E, Lubin V, Ury $P$, et al. Insuffisance corticotrope et diabète sucré secondaire à l'usage des dermocorticoïdes à visée cosmétiques. Ann Endocrinol 2003; 64:203204.

15. Raynaud E, Cellier C, Perret JL. Dépigmentation cutanée à visée cosmétique: Enquête de prévalence et effets indésirables dans une population féminine sénégalaise. Ann Dermatol Venerol 2001; 128(6-7):720-724. 